\title{
6. Insights from Joseph Schumpeter
}

\section{Richard N. Langlois ${ }^{1}$}

The aspect of Joseph Schumpeter that I usually think about and talk about is his ideas about the large corporation and the evolution of capitalism more generally. I will discuss some of these matters today, but will also move out of my comfort zone and consider what this great economist might have to say about the recent financial crisis and today's trying economic times.

Schumpeter, like his rival John Maynard Keynes, was born in 1883. He was born in one of the outposts of the Austrian Empire and educated at the University of Vienna under Eugen von Böhm-Bawerk and Friedrich Wieser, who were the second generation of what is sometimes called the Austrian School of Economics. The initiator of the Austrian School was Carl Menger, one of the so-called marginalist revolutionaries, who in the 1870s changed the way we thought about economics. Böhm-Bawerk and Wieser were Menger's students, so Schumpeter was kind of a third-generation Austrian economist. Friedrich Hayek - the subject of Bruce Caldwell's Insights lecture - would have been the fourth generation, 
because he was almost two decades younger than Schumpeter.

Schumpeter started his professional career at the University of Cernowitz, before moving to the University of Graz, the University of Bonn, and eventually Harvard. A great story from Cernowitz gives you an idea about Schumpeter's personality. He wanted to put some books on reserve in the library for his students, but the librarian objected, so Schumpeter and the librarian had a fencing duel! Apparently, they became fast friends afterward.

He had real world experience with finance and financial crises. Schumpeter was the Austrian Finance Minister after World War I, which was a time of hyperinflation in Central Europe. Then he was president of a private bank, which collapsed. For most of the rest of his life he spent much of his earnings as a professor to pay back the people that he owed money to in this collapse.

Schumpeter came to Harvard in the 1920s, and spent the majority of his career there. He was a very open-minded and tolerant professor. Among his many notable students were Paul Samuelson and James Tobin, who became Nobel Laureates and helped invent the mainstream economics that emerged after World War II. But his student Paul Sweezy was a Marxist and future Nobel-winner Wassily Leontief was a specialist in mathematical programming.

Like Keynes, Schumpeter died young. Keynes reached 62; Schumpeter died at 66. Schumpeter 
was prolific, but let me concentrate on four major works. The Theory of Economic Development, which he wrote in German, came out in 1911 (an English edition of part of the second German version was published in 1934). Business Cycles (1939), a two-volume 1,000-page tract, is almost crushingly boring, and it is nearly impossible to read. This was the book Schumpeter hoped would be his magnum opus, which would crown him as the greatest economist of the time. Schumpeter was dispirited, especially as World War II started, and during World War II he wrote Capitalism, Socialism and Democracy (1942). It was more of a popular book, a very brooding book in which he predicts the end of capitalism. Finally, he also wrote another 1,000-page book on The History of Economic Analysis (1954), although it was not published until four years after he was dead. Fortunately, he had married an economist - Elizabeth Boody Schumpeter - and she finished it for him.

Schumpeter and Keynes were rivals and almost everybody would have said for a long time that it was not a contest. If you studied economics in the 1960s and 1970s you might have gone through graduate school and never even heard about Schumpeter. The focus was on Keynes, or modern Keynesians like Tobin or Samuelson, filling the textbooks.

Arthur Diamond (2009) has examined the trend in citations to Schumpeter and Keynes (Figure 6.1). From the mid-1950s until about 1990, citations levels were similar, but Keynes was 


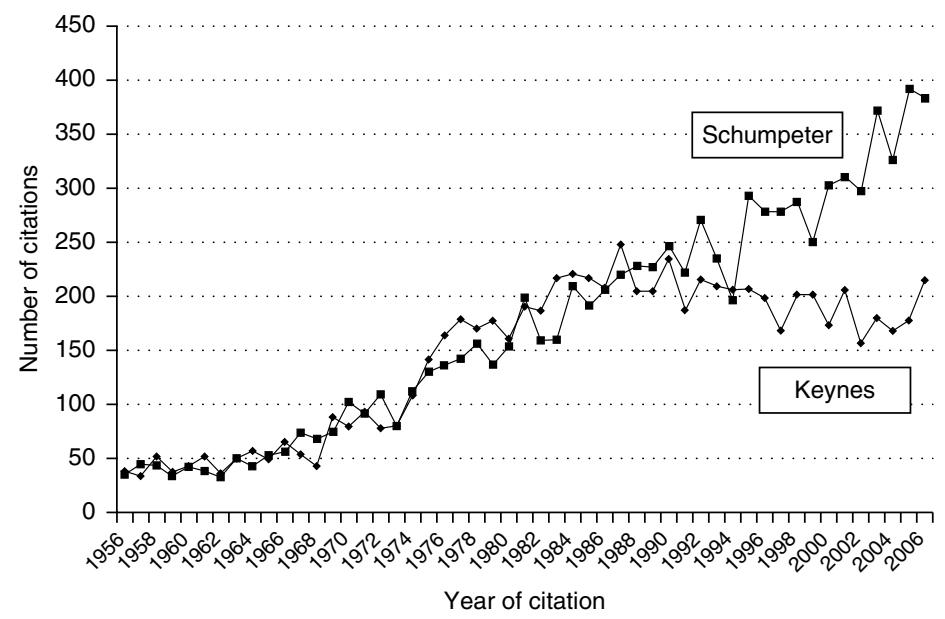

Source: Diamond (2009)

Figure 6.1 Schumpeter versus Keynes: total citations per year to all publications

usually somewhat ahead. But around 1990 Keynes plateaued and citations to Schumpeter climbed strongly. What was going on in the 1990s? The 1990s was the decade of entrepreneurship and the high-tech boom, and everybody started quoting Schumpeter, while fewer worried about Keynes. So maybe in the end Schumpeter got his wish and bested Keynes.

Let us turn to Schumpeter's ideas. Schumpeter coined the widely used term 'creative destruction'. This sounds like an oxymoron. How can destruction be creative? Schumpeter's key idea was that capitalism is a dynamic process. Most economics courses think about economics as being about the allocation of resources. If you pick up any intro- 
ductory textbook you are taught about the allocation of resources in a world where people have unlimited wants but limited resources. We want to make sure that scarce resources get allocated efficiently. This, the textbooks argue, is what is good about markets: markets and the price system figure out how to allocate resources efficiently.

But Schumpeter disagreed with that emphasis. Yes, markets are good at allocating resources efficiently. But if you look at history, you will see ever-expanding capabilities being created by capitalism. So, capitalism is not really about the optimal allocation of resources, it is about shifting out the production possibilities curve. The way Schumpeter thought about it, the only interesting question is how the production possibility curve gets shifted out. Here is how he puts it in Capitalism, Socialism, and Democracy (1976 edition, pp. 82-83):

Capitalism, then, is by nature a form or method of economic change and not only never is but never can be stationary. And this evolutionary character of the capitalist process is not merely due to the fact that economic life goes on in a social and natural environment which changes and by its change alters the data of economic action; this fact is important and these changes (wars, revolutions and so on) often condition industrial change, but they are not its prime movers. Nor is this evolutionary character due to a quasi-automatic increase in population and capital or to the vagaries of monetary systems, of which exactly the same thing holds true. The fundamental impulse that sets and keeps the capitalist engine in motion comes from the new consumers' goods, the new methods of production or transportation, the new markets, the new forms 
of industrial organization that capitalist enterprise creates. (emphasis added)

Schumpeter is saying that innovation is the key. Instead of thinking about where the supply curve meets the demand curve, we need to think about where these curves come from, especially the supply curve, and to think about the capitalist process as a process of constantly creating new supply curves and shifting them out.

Notice what he lists as innovations. It is the kind of things that we thought about during the high-tech boom of the 1990s - such as computer technology. And it is globalization. He talks about opening up new markets. The 1990s saw the reawakening of globalization, the kind of globalization that had not occurred since before World War I. The nineteenth century and the period leading up to World War I was also a time of globalization. (Although much of the movement was people, not just goods; this was an era of mass migration.) All of that came to a halt with World War I. The economic historian Deirdre McCloskey (2006, p. 11) talks about the Great European Civil War, 1914-1989. Almost the entire twentieth century was really unusual from World War I up to the fall of the Soviet Union. It was marked by two world wars, the spread of communism, and the Great Depression. By 1989 all of these things had gone away and we went back to a period of growth.

What would Schumpeter have had to say about 
the financial crisis? After all, he wrote a 1,000page, two-volume book called Business Cycles. Somewhere in it there must be something about financial crises. Schumpeter's point was that innovation is not just about new products like computers and cellphones; there is also financial innovation. Think about junk bonds back in the 1980s, or derivatives, or mortgage-backed securities, or hedged instruments. Those are financial innovations. But in discussing Schumpeter's insights for today's trying economic times we must also consider the issues that he was so concerned about in Capitalism, Socialism and Democracy the future of capitalism and how changes in capitalism subsequently change culture, and how this dynamic affects the future of capitalism. An example of this dynamic that everybody is interested in today is the Occupy Wall Street movement. $^{2}$

I want to talk about the financial crisis first in terms of the way it is now being discussed and then ask how Schumpeter would have discussed it. A recent paper by Douglas Elliott and Martin Baily (2009) of the Brookings Institution argues that there are three narratives about the financial crisis. Narratives are important, because narratives are the way we really come to understand things. You can write equations and draw curves, but what really makes people - especially people who are not sitting in economics classes - understand things is to tell it as a story. Narrative 1 says the financial crisis was really the fault of the government, 
which encouraged the housing bubble and then also handled things badly once the crisis occurred. Narrative 2 - the Occupy Wall Street narrative says that it was all Wall Street's fault: it was greed, arrogance, and stupidity. If we want to give it a more sophisticated spin we can talk about misaligned incentive structures within the financial sector. And everybody is fixated on compensation of people who were making lots of money. The narrative (number 3) that Elliott and Baily favor says that everybody was at fault, in the sense that we were all kind of tricked because we thought that the business cycle had been tamed. The 'great moderation' over the couple decades before the crisis saw a lot of economic growth, low inflation, and no important recessions. People began to think that this meant we had figured out how to tame the business cycle; that the Federal Reserve now knew how to do it; we have all learned how to do it; so now there is nothing to worry about. And when we stopped worrying we took on more risk and leverage, and maybe also stopped worrying about financial regulation.

Part of Narrative 2 is the criticism that deregulation of financial markets was a big part of the problem. But the people who like Narrative 1 would say, although there was some deregulation, much regulation remained and the regulatory authorities had plenty of power to stop this crisis if they had been smart enough to know there was a crisis. Moreover, a lot of the bad subprime loans were guaranteed and subsidized by the federal 
government. As of June 30, 2008 there were 27 million subprime and Alt-A loans. Fannie Mae, Freddie Mac, the Federal Housing Administration (FHA) and other federal government agencies were the source of 19.2 million of them, which had an unpaid principal amount of $\$ 2.7$ trillion - almost 60 percent of all these loans (Wallison, 2011). In fact, much of the private low-quality loans were strongly encouraged by government. There was a longstanding bipartisan government project to make it easier for people with low incomes and poor credit to own houses. In the Clinton Administration this was spun as helping lower-income people. In the Bush Administration it was spun as 'the ownership society'.

In addition, consider the real interest rate. Starting in the early 2000s and heading up to the crisis, the real interest rate (measured as the stated federal funds rate minus the inflation rate) was negative. Loosely speaking, we had easy money. The Federal Reserve pumped a lot of money into the system after the dot-com boom went bust. One of the lessons of the Great Depression that the Federal Reserve, especially Chairman Ben Bernanke (who wrote about the Depression as an academic economist), has taken on board is that the central bank must make sure not to let the money supply decline. If there is a recession, the Federal Reserve has to act quickly to pump money into the system. Narrative 1 sees all this as the government instigating lots of bad mortgages, pumping money into the system to finance 
these mortgages, and blowing up the balloon. Eventually real interest rates started to go back up, and the balloon burst.

Narrative 3 notes that housing and housing loans are complementary goods. In the seven-plus decades following the Great Depression, nominal housing prices never went down. So virtually nobody alive had ever seen nominal housing prices go down. Lenders began to think that when borrowers with poor credit could not pay their loans, all they had to do was refinance, because their house would be worth more tomorrow than it was yesterday; they could use that extra magic equity to refinance. So why should the housing lender worry about defaults? In a sense, this was rational. The data from before the crash show that as prices went up default rates fell. Before these trends reversed, it made sense to be blasé about risk (Figure 6.2).

What would Schumpeter have said about all this? Here is his 1,000 page book in three bullet points. Point one: Entrepreneurial innovation creates a disequilibrium as resources move from old less-valued uses to new more-valued uses. Point two: This disequilibrium is the business cycle. Point three: Entrepreneurial innovations are not independent but appear in correlated 'swarms'.

Schumpeter imagines an economy that is kind of cruising along doing things the way it always used to do things - when suddenly somebody notices that if we invent some new thing - say we 


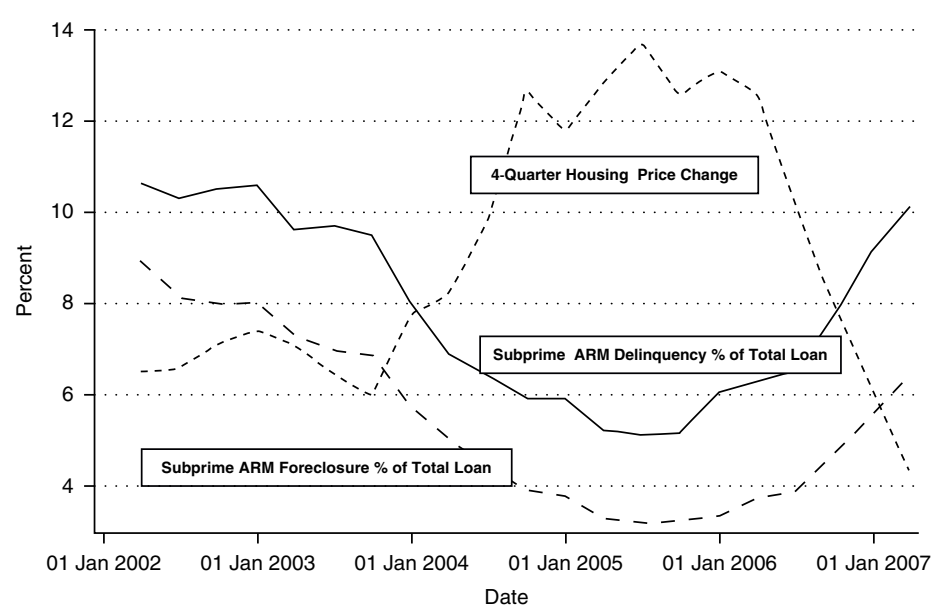

Source: Mortgage Bankers Association and OFHEO

Figure 6.2 Housing prices and subprime ARM delinquency and foreclosure rate

put a lot of transistors all on the same substrate of silicon, so we can make lots of transistors at the same time - that will be useful for lots of things, and we can make lots of money. As entrepreneurs pursue the innovation, it disrupts this equilibrium, because now there is a better allocation of resources. The actions of entrepreneurs create a disequilibrium; they upset the apple cart in an economy that was humming along doing things that it had always done.

Often we are taught in economics that if someone picks up a 5-dollar bill from the ground, it will not cause any disequilibrium. But in Schumpeter's case it is not just someone picking up one 5-dollar bill - it is people picking up a bunch of 5-dollar 
bills. So imagine you see a 5-dollar bill and you pull on it and it turns out that it is actually taped to a whole bunch of other ones that are underground. Schumpeter would say that a single entrepreneur is not going to cause disequilibrium because people are always changing things, and what one person does is going to offset what somebody else does. It has to be that things are correlated, that the innovation that this entrepreneur brings forth is correlated with a lot of other things. Innovations do not come one at a time, they come together in swarms. If you invent the semiconductor chip that means we can have computers, and we can have cellphones, and we can change the way offices work, and we can change the way telecommunications systems work; this one invention changes all kinds of things that are linked to it.

Schumpeter has a very sociological theory about the entrepreneur and capitalism. His view is that entrepreneurship is hard because people put up a fuss if you try to disrupt an equilibrium. People like things the way they are. They do not like change. This entrepreneur comes along and says, we are going to change the way we do everything; and people resist. If some entrepreneur has got enough gumption, enough vision, enough energy to break through what Schumpeter calls the 'crust of convention', then all of a sudden the convention is broken. So people say, maybe it's okay to computerize this office, and I don't need carbon paper anymore after all. That makes it easy for other entrepreneurs to come along and say, hey, 
he just broke the crust; let's dive in. So they all dive in because the first entrepreneur broke the crust.

There is a related view that economists interested in Schumpeter's ideas have recently put forward, the idea of a 'general purpose technology'. A general purpose technology is one that could be used for many, many different things. Electricity is a general purpose technology. So if you invent an electrical generation system - you are Thomas Edison and/or Nikola Tesla - it can be used for all kinds of different things. This means that a lot of things in the economy have to change. It means that even things like the kinds of buildings we live in and the kinds of factories we build have to change. In the nineteenth century factories were designed around a giant steam engine or water wheel. They would have a shaft running through the attic, and everything would be connected to the shaft. But if you have small electric motors you do not need to have that kind of factory. Maybe you do not need to have all your equipment and material in the same building. Maybe you do not even need to have it all owned by the same people. So everything begins to change. Semiconductors, computers, and perhaps the automobile were general purpose technologies. Technology is linked. It is complementary to lots of other things. So if one thing changes then at the same time lots of other things change.

But why does this cause a disequilibrium? In Schumpeter's view the money economy and the 
real economy are not the same thing; but they can affect each other. Schumpeter rejected the idea that savings and investment are always equal to each other. Suppose that we are undertaking an innovation in a centrally planned economy. In a centrally planned economy some economic czar could say: let's get rid of all the carbon paper and start using computers. The economic czar could get rid of the carbon paper at the same time that they installed the computers. If you know everything and you are an omnipotent central planner, you can do these kinds of things, so there is no disequilibrium. We take resources away from less valued uses. We move them instantly to higher valued uses.

But, of course, in the real world it does not work like that, because the innovators have to get financing from somebody. Schumpeter thinks about financing as coming mostly from banks. Partly that is a simplifying assumption. Partly that is how the world worked when he was around - and you have to remember, he was the president of a bank. So entrepreneurs come to banks. In his model banks are never at their limit of credit creation. They can always create a little more if somebody has a good idea. So they create more credit to fund these entrepreneurs. But that creation of new credit does not get transmitted to the people with the carbon paper. They do not stop making the carbon paper right away. So there is an economic boom that starts as the new technology spreads. It creates what Schumpeter calls 
a secondary boom that is artificial. Because what should be happening is that resources should be being withdrawn from carbon paper at the same time they are being put into computers. But that does not happen. The carbon paper is still there because those signals have not yet reached those who finance carbon paper. Yet there is a boom in computers. The whole process is not sustainable.

The second part of the story behind the disequilibrium, Schumpeter says, is that when all this is happening we do not know what the outcome is going to be. Think about the dot-com bubble. Some people said: this is a bubble. All these investors are valuing the dot-com companies and companies like Enron ridiculously high. They are stupid. Could they not see that those stocks were overvalued? Saying something is overvalued is easy with hindsight, but in reality it is very hard to tell while you are in this disequilibrium, because this is a new technology. Nobody knows how to value it. So nobody really knows the value of this new technology. And if you say it is eventually going to be a bubble someday, you can miss out. Suppose that in 1996 you said, I know there is going to be a bubble, these stock prices cannot keep going up, I am getting out of the market. Eventually there was indeed a bubble. But if you left the market in 1996, you missed out on fantastic wealth that you would have had if you had stayed in the market four more years.

Schumpeter's theory fits events like the dot-com boom and bust pretty well. He was quite familiar 
with crises in history. There was a lot of speculation taking place when electricity emerged as a general purpose technology. There were many technologies throughout history that people did not know how to value.

In the dot-com bubble, the role of technology was clear - it was the Internet, semiconductor technology, computer technology. All of those were general purpose technologies. All of them were big. All of them were new. We did not know how to value them. But what about a housing boom? Where is the new technology for a housing boom? I think Schumpeter has a problem here. You might argue that the innovation was a financial innovation. But if you read the 1,000 pages of Schumpeter's Business Cycles you will discover that Schumpeter does not actually want to count financial innovations as genuine technological innovations. This is partly because he is kind of walling off the banking sector. The banking sector plays a financial role in his theory, but he cannot very well have the banking sector be part of the other part of the theory.

Other scholars, like the economic historian Niall Ferguson (2008) or financial economists Rajhuram Rajan and Luigi Zingales (2003), credit financial innovation with a lot of economic growth in the nineteenth and twentieth centuries, arguing that you do not really get economic growth until you get well functioning financial markets. Financial innovation is about lowering transaction costs, about thickening markets so they work better. But 
there is some mixed evidence that Schumpeter was actually rather hostile to financial innovation. He did say that the invention of fractional reserve banking was an important innovation, but on the other hand, he favored regulating financial markets to curb innovation.

Schumpeter was a devotee of technical business cycle analysis: the notion that there are natural waves, and innovation comes in these natural waves. The problem is that actual business cycles look nothing like sine waves. They have all kinds of funny shapes. Schumpeter would counter that this is because a bunch of different waves are being overlaid. There are Kitchin cycles on top of Juglar cycles on top of Kuznets cycles on top of Kondratieff cycles. If you add up those sine waves they give you all kinds of funny shapes and that is what is going on. So he might say today that the recession was just the downturn of the Juglar fixed-investment cycle.

In a sense, recent events may be just the aftermath of the dot-com crash. That is sort of what Narrative 1 is saying, too: because of the dot-com crash both Alan Greenspan and Ben Bernanke were very aware of the need for the Fed to keep liquidity high, to put money into the system to prevent deflation. When there is a stock market crash or a housing crash all of a sudden people's equity disappears. If you have money in the stock market and the stock market goes down, you feel poorer than you were, and you reduce spending. Same thing if the equity in your house disappears. 
The Fed wanted to counter that by putting more money into the system. And one argument is that they just put too much money into the system. After the dot-com bust, the stock market stopped looking like a good investment. So where do we put our money? We can't just invest in loans, because the real interest rate is negative. Ah, but housing prices have never gone down in real terms. Why don't we put our money in houses? And why don't we go into more risky financial instruments? After all, zero-risk instruments have negative returns. We have to go into more and more risky instruments in order to make a decent return. Add the Fed's response to the dot-com bubble burst and - poof - you get the housing bubble.

Here is a passage right in the middle of Schumpeter's Business Cycles (p.635):

We do not, of course, hold that the behavior of banks has nothing to do with the cycle. There is no doubt that without credit creation amplitudes of cyclical fluctuations would be much smaller, although there have been (witness England in the forties) even 'manias' with very little credit creation, and although the effect on money rates is not the most important lever through which it works. In particular, the phenomena of the secondary wave would then be much less in evidence. Although even these are induced not by money rates being too low but by entrepreneurial activity, higher money rates would go far toward keeping them in bounds and low money rates tend to foster them. Judgment in granting loans is much more important than the rate charged, and reckless banking does not consist in financing cheaply but in financing irresponsibly. But effects would be mitigated 
if, given a certain amount of irresponsibility, credit were made more expensive. What should be evident more than anything else is that a cheap money policy in prosperity can have no other effect than to accentuate excesses and subsequent breakdown.

Although I talked only about the Fed, Schumpeter's credit creation occurs through banks, which would include the Central Bank. His view is that banks can never cause a crisis; but they make things worse. This quote is very relevant to the recent financial crisis. He says: 'Judgment in granting loans is much more important than the rate charged ... Reckless banking does not consist in financing cheaply, but in financing irresponsibly.' Remember the extent of subprime loans - that is bad judgment in granting loans, that is recklessness - which is much more important than the interest rate.

Schumpeter would be called an accommodationist. He thought about monetary policy as just going along with what the economy needs, unlike a monetarist, like Milton Friedman, who viewed monetary policy as the lever that we can use to control things. Schumpeter, more like Keynes, would have said that money just goes along for the ride; what is really important is the real things that are going on, like technological innovation.

Schumpeter criticizes 'a cheap money policy in prosperity'. He means the real interest rate being negative in the middle of the 2000s decade, a period of prosperity. He argued that 'cheap money during prosperity can have no other effect 
than to accentuate excesses and subsequent breakdowns', but he did not think of it as an independent cause of things.

Let us wind up with Schumpeter thinking about the fate of capitalism, especially in Capitalism, Socialism, and Democracy. In many ways Capitalism, Socialism and Democracy was really a debate with Marx. Schumpeter saw himself as a rival of Marx. Marx's theory was that capitalism is going to self-destruct because of flaws inherent in the capitalist process. Schumpeter's argument is there are not flaws in the capitalist process; if you leave it alone it is extremely successful. But what will doom capitalism is, in Schumpeter's view, its very success. How can that be? You need entrepreneurship to keep capitalism going; but by the middle of the twentieth century, we did not seem to need bold entrepreneurs anymore, because now we had big research labs and people with white lab coats and test tubes. And when you have white lab coats and test tubes you do not need to have entrepreneurs to introduce innovation; all you need are big companies. It is like Mad Men - somebody sitting around in an office says: we need a four-slice toaster, or a four-blade razor. Innovation starts to come from the men in their offices, not from bold entrepreneurs. They send the scientists off to figure out how to make a four-blade razor, and then they introduce it.

But if we do not need entrepreneurship anymore, then we do not need capitalism 
anymore. If we can do things kind of automatically by bureaucracies and people with white lab coats and test tubes, then we do not need capitalism. At the same time, Schumpeter said, there are a lot of people who do not like capitalism - a new class of anti-capitalist intellectuals, who think capitalism is greedy and think it is not a very good civilization. They think things could be run better if they were run by the government. But because the entrepreneurs have been replaced by bureaucracies, there are no more mythic heroes left. Without the entrepreneurs who were the mythic heroes who justified capitalism, the whole system is going to go to pot. Not because it was unsuccessful, but because it was so successful in creating wealth that the entrepreneur became obsolete, and the wealth created a kind of disaffected class of wealthy types who hang around hating capitalism, and they are going to take over.

Is this true? Is the age of the entrepreneur over? Steve Jobs just died and everybody is thinking about this. Maybe entrepreneurs have not gone away. On the other hand, we can ask the question, what effect do financial crises have on people's faith in capitalism? Schumpeter was writing at the tail end of the Great Depression, and was keenly aware of what he called the 'radicalization' that took place during the Great Depression. People were disaffected and they blamed capitalism that was the dominant narrative of the Great Depression. 
If we take him seriously, capitalism should have been dead by 1980, because he would say things like 'in another 20 or 30 years this will happen'. Schumpeter was writing in the 1940s and he thought, as George Orwell seems to suggest in 1984 , that by the 1980s capitalism would be dead. There is, however, an argument, which I endorse, that Schumpeter does not literally mean what he says in Capitalism, Socialism and Democracy. He is in fact ridiculing the idea of socialism while superficially seeming to praise it. Except perhaps for some economists and a few other social scientists, intellectuals do not have any sense of humor, so they took him seriously when he meant to be darkly sardonic.

So what would Schumpeter say if he were around today? I think that on the large question of capitalism, his response would be clear: we should leave the system alone and let entrepreneurs continue to seize growth-producing profit opportunities. Schumpeter in his own day accused the Roosevelt administration of causing what the economic historian Robert Higgs (1997) called 'regime uncertainty' - a fear-inducing uncertainty about the rules of the game under which business will have to play. Schumpeter would likely have added his voice to those who are worried about such uncertainty today; uncertainty prompted by changing monetary, regulatory, and bail-out policies. As I have hinted, though, Schumpeter would probably have been a skeptic of financial innovation, and it is far from 
clear what he would have said about regulating (for example) financial derivatives. It is certainly clear, however, that he would have opposed policies that debase lending standards and, perhaps to a smaller extent, the loose-money policies of the central bank.

\section{Notes}

1. This talk was given at Wake Forest University on November 8, 2011.

2. Recently about 60 (out of about 750) students at Harvard walked out of Greg Mankiw's introductory economics class to protest the pro-market-economy views he was articulating in this class. I was quite put off that none of my students did that, because I was saying more 'outrageous' things than Mankiw.

\section{References}

Diamond, A. (2009), 'Schumpeter Vs. Keynes: "In the Long Run Not All of Us Are Dead"', Journal of the History of Economic Thought, 31, 531-541.

Elliott, D.J. and M.N. Baily (2009), Telling the Narrative of the Financial Crisis: Not Just a Housing Bubble, Washington, DC: Brookings Institution.

Ferguson, N. (2008), The Ascent of Money, New York: Penguin.

Higgs, R. (1997), 'Regime Uncertainty: Why the Great Depression Lasted So Long and Why Prosperity Resumed After the War', The Independent Review, 1 (4), 561-590.

McCloskey, D.N. (2006), The Bourgeois Virtues: Ethics for an Age of Commerce, Chicago, IL: University of Chicago Press.

Rajan, R.G. and L. Zingales (2003), 'The Great Reversals: The Politics of Financial Developments in the Twentieth Century', Journal of Financial Economics, 69, 5-50.

Schumpeter, J.A. (1934), The Theory of Economic Development, Cambridge, MA: Harvard University Press.

Schumpeter, J.A. (1939), Business Cycles: A Theoretical, Historical, and Statistical Analysis of the Capitalist Process, New York: McGraw-Hill Book Company. 
Schumpeter, J.A. (1942), Capitalism, Socialism, and Democracy, New York: Harper \& Brothers.

Schumpeter, J.A. (1954), History of Economic Analysis, edited by E.B. Schumpeter, New York: Oxford University Press.

Wallison, P.J. (2011), 'Three Narratives About the Financial Crisis', The Cato Journal, 31 (3), 535-549. 